\title{
特発性内反母趾の治療経験
}

\author{
南風病院整形外科 \\ 富 村 奈津子.川 内 義 久 \\ 和 田正一領 木 良 浩
}

\section{A Case of Idiopathic Hallux Varus}

\author{
Natsuko Tomimura, Yoshihisa Kawauchi, Shoichi Wada \\ and Yoshihiro Ryouki \\ Department of Orthopaedic Surgery, \\ Nanpuh Hospital, Kagoshima
}

\begin{abstract}
An unusual case of idiopathic hallux varus is reported in this paper. A 63 year-old woman presented with hallux varus deformity accompanied with pain and showed no evidence of underlying inflammatory disease nor history of trauma. This case had 42 degrees of the pre-operative varus deformity. Muscle release and reconstruction without osteotomy resulted in good alignment of the great toe and the patient was cured of gait disturbance with pain.
\end{abstract}

Key words : Hallux varus (内反母趾), idiopathic（特発性）

\section{はじめに}

今回我々は極めて稀な特発性内反母趾の 1 例に対し, 観血的治療を行い良好な結果が得られたので報告する.

\section{症例}

症例は 63 歳の女性である.

既往歴に特記すべき事項はない，血液生化学所見に 異常なく，RA 因子も陰性であり，明らかな外傷歴は ない.

17 年前より右母趾の変形に気付いていたが痛みは なく放置していた，H 8 年 11 月頃より右母趾痛が出 現し，歩行時痛が次第に增強してきたため，近医を受 診した．消炎鎮痛剂の内服にて症状は軽快せず， H 9 年 6 月 25 日当科を受診した。

初診時, 右母趾は MP 関節部で強く内反し, 同部 に腫脹・圧痛を認めたが熱感はなかった。他の足趾に も内反変形が軽度認められ，第 $3 \cdot 4$ 趾趾間関節は屈 曲拘縮がみられた（図1-a）。
単純 X 線像では，第 1 中足骨に対する基節骨の内 反角は $42^{\circ}$ であった．MP 関節部には骨硬化像を認め た(図 2-a).

7 月 26 日手術を施行した。母趾内側に約 $12 \mathrm{~cm}$ の 皮切を加え，母趾外転筋を確認し，これを基節骨付着 部にて切離した，母趾外転筋は足底方向に偏位し，筋 腹は正常よりかなり中枢側に偏位していた，MP関節 の肥厚・瘏痕化した関節包を切除し, 足底部の線維性 癒着を剥離したが母趾の整復は不十分であった。

次に第 1-2 趾趾間に $\mathrm{S}$ 状切開を加え, 第 2 趾の短趾 伸筋を付着部より切離し，癞痕組織のなかに包まれて いた母趾内転筋の付着部を確認した。 母趾内転筋は足 底方向に偏位していた，母趾内転筋を関節包付着部に て切離し，関節包を縫縮した後，基節骨にdrilling を行い，短趾伸筋と母趾内転筋を内側に pull out $L$ た。この操作で母趾は良肢位に固定された。

切離した母趾外転筋を第1中足骨に縫縮した後に， Kirschner 鋼線にて趾尖より中足骨まで固定し，術 後は下腿から足尖までのギプスシーネ固定とした。 


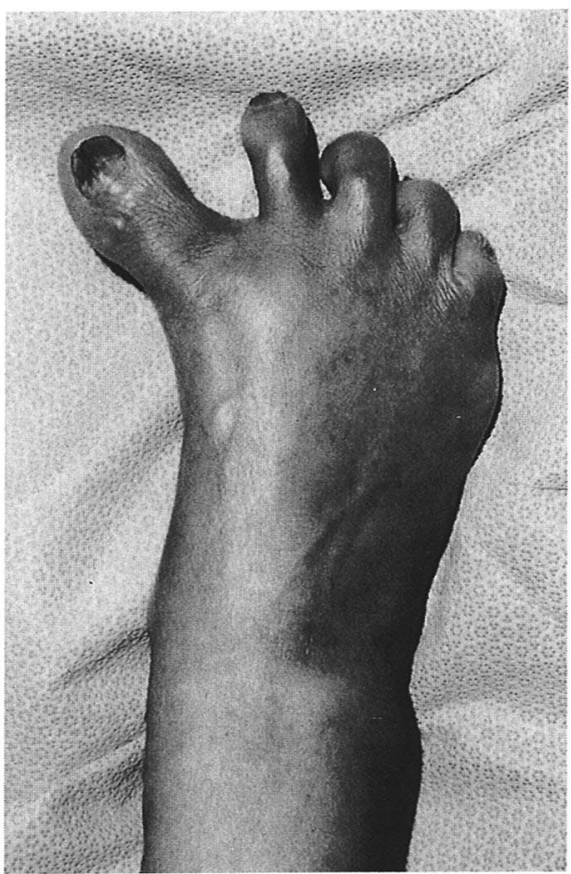

図 1-a 初診時肉眼所見

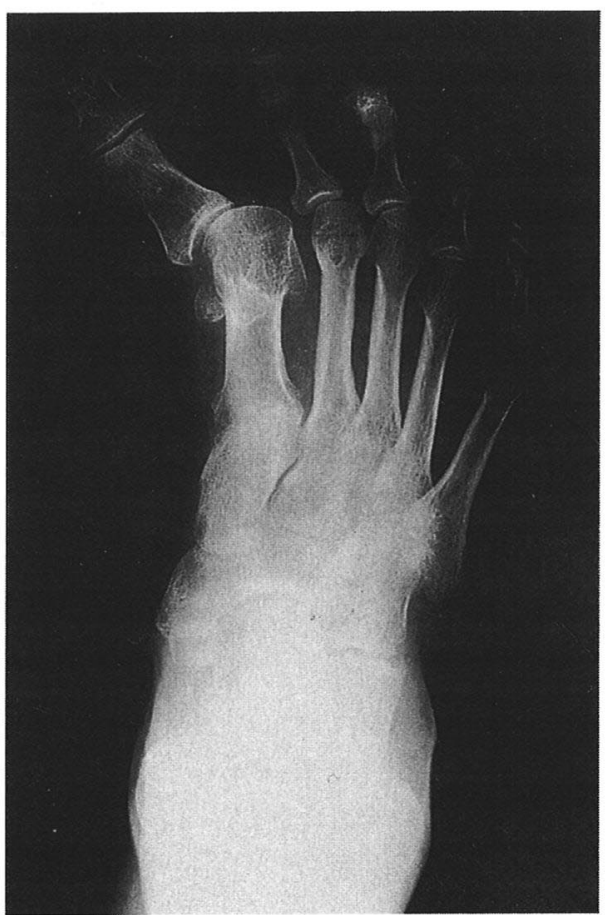

図 2-a 初診時 X 線写真

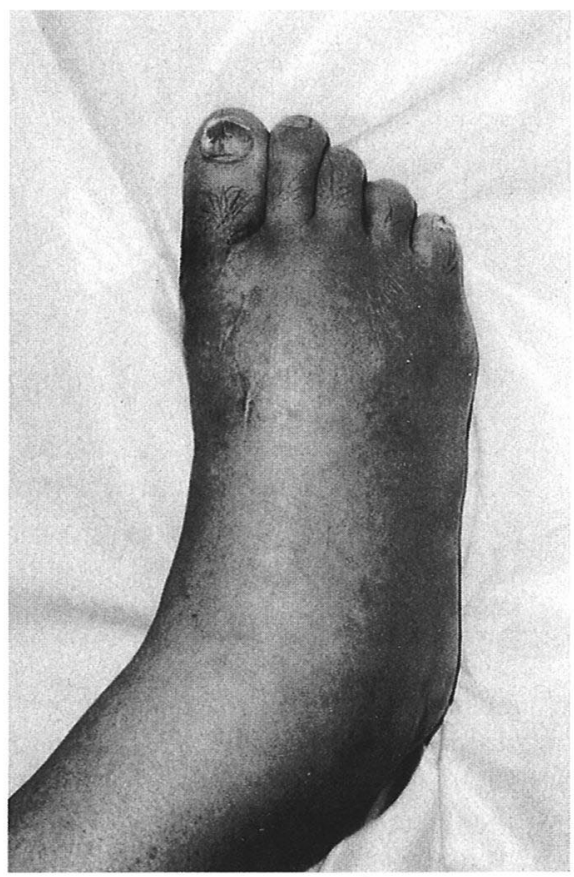

図 $1-b$ 術後肉眼所見

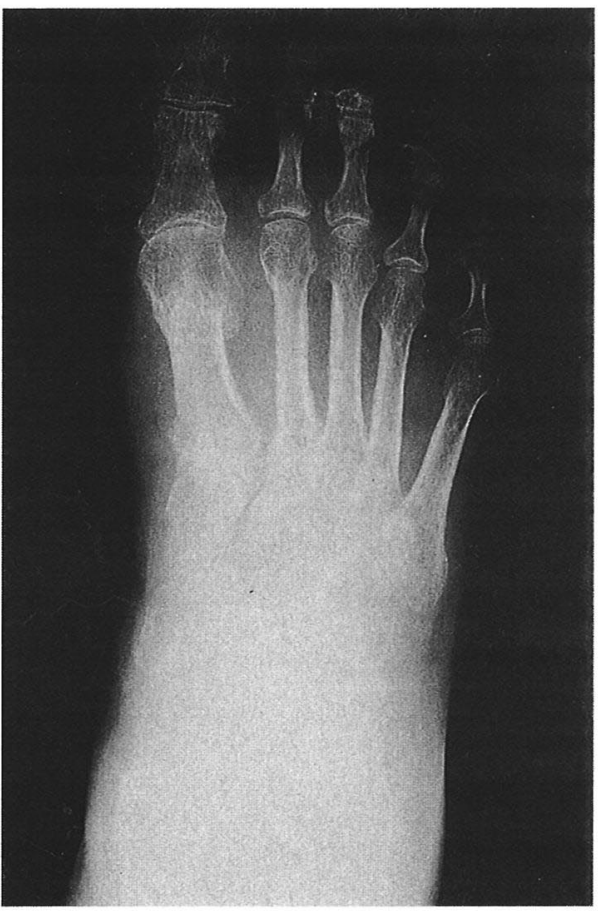

図 $2-b$ 術後 X 線写真 
術後 3 週間で Kirschner 鋼線を抜釘し母趾の自動 運動を開始，5 週後より歩行を許可した。歩行開始時 には術前にみられた歩行時痛は消失した。単純 X 線 上母趾は内反 $42^{\circ}$ が外反 $20^{\circ}$ となり（図 2-b)，現在 まで過矯正変形も認めず，経過良好である（図 1-b).

\section{考察}

内反母趾変形の原因として，1）先天性，2）多趾症 に伴うもの，3）外反母趾矯正術後の過矯正，4）外傷 性，5）RA に合併寸るものなどの報告がみられるが, 本症例のように特発性と考えられる症例は稀で”, 我々 が渉猟しうる限り本邦では羽鳥ら ${ }^{3 \prime}$ の報告の 1 例のみ であった，羽島らは自験例の内反母趾発症要因の 1 つ として下䭾や草履の使用により長年にわたり母趾 MP 関節に内反ストレスが加わっていたことを挙げている が本症例ではそのような生活習慣はなく，発症要因は 不明である。

手術法については様々な報告214) をみるが本症例で は，母趾外転筋・内転筋の緊張や関節包の肥厚 ·痒痕
化を認め，それら軟部組織の処理のみで骨切りを行な うことなく整復位を得ることができた。術後 10 力月 を経過した現在も過矯正変形を認めず，経過良好であ る.

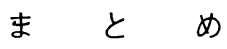

(1)特発性内反母趾の 1 例を報告した。

(2)内反母趾変形に対し観血的治療を行い良好な結果 が得られた。

\section{参 考 文 献}

1) Davies, M.S., Parker, B. C.: Idiopathic Hallux Varus. Foot Ankle, $16: 210-211,1981$.

2) Granberry, W. M., Hickey, C. H.: Idiopathic Hallux Varus. Foot Ankle, 15 : 197-205, 1994.

3) Hatori, M., Ito, K., Kokubun, S.: Idiopathic Hallux Varus. The Foot, 6 : 145-147, 1996.

4) Jhonson, K. A., Spiegl, P. V.: Extensor hallucis longus transfer for hallux varus deformity. J. Bone Joint Surg., 66A : 681-686, 1984. 